ORIGINAL RESEARCH PAPER

\section{STUDY OF THYROID DYSFUNCTION IN ELDERLY PATIENTS MORE THAN 65 YEARS OF AGE GROUP}

\section{General Medicine}

KEY WORDS: Hypothyroidism Hyperthyroidism, Subclinical hypothyroidism, Subclinical hyperthyroidism, Elderly,TPO,Total chol,LDL

\section{Dr Jitendra} singh*

\section{Dr Pankaj Hans}

Post graduate Patna medical college and hospital, Patna*Corresponding Author

Associate professor Patna medical college and hospital, Patna

Aims and objectives: To study thyroid dysfunction and its clinical correlation in elderly patients more than 65 years of age group in Patna medical college \& hospital, Patna. Material \& methods: This study was conducted on 100 elderly patients in the department of medicine, Patna medical college \& hospital, Patna. All patients of age more than 65 years with clinical suspicion of thyroid disorders were included in this study. All suspicious patients were examined clinically for detection of thyroid disorders. The laboratory evaluation of thyroid functions was done by estimation of serum T3,T4 and TSH levels by Chemiluminescence assay method. chi-square test was used for statistical data analysis. Results:In this study 100 elderly patients in the age group of more than 65 years were included. Out of which, 30 patients were found to have abnormal thyroid function test, of which 23 patients had clinical features suggestive of hypothyroidism $(13+10)$ and 7 patients had clinical features suggestive of hyperthyroidism (3+4).We have noted that as the age advances the incidence of thyroid dysfunction increases. Conclusion : Aim of this study was to know the various clinical aspect of presentation of thyroid dysfunction in the elderly population that differ from typical presentation.Incidence of thyroid dysfunction increases with increase in age.

\section{Introduction:}

Thyroid disorders are the commonest endocrine disorders in the general population. They often represent chronic conditions their prevalence increases by age and reaches to the highest rate in elderly.In India 60 years and above is considered as geriatric population. Even though Indian statistics regarding thyroid dysfunction in elderly is sparse, a study by Rebecca et al2 from Puducherry showed that $19 \%$ of women over 60 years had elevated TSH above $4.5 \mathrm{IU} / \mathrm{ml}$ and the percentage of women with elevated TSH was particularly high in the 60-80 years age group. Health care professionals should become and remain aware of the changes that distinguish older from younger patients, because these changes bring new challenges in clinical care resulting from the special needs associated with both normal aging and its related chronic illnesses 4 .Hypothyroidism occurs in $10 \%$ of females and $2 \%$ of males in patients older than 60 years 5 . The prevalence in the elderly is approximately $2 \% 5$ but from another perspective, 10 to $15 \%$ of patients with hyperthyroidism are older than 60 years. In the elderly, the diagnosis is moreoften overlooked or misdiagnosed, as the symptoms are often subtle or absent and are easily confused with coexisting illnesses. Thyroid gland undergoes slight physiological changes with aging, either as a result of its participation in the senescence process or as an effect of other system changes.Symptoms of hypothyroidism such as tiredness, fatigue, lack of concentration, or dry skin can be very similar to complaints associated to aging[9]Symptoms may often be attributed to normal aging, and a high index of suspicion of thyroid dysfunction in the elderly is needed6. The management of thyroid disorders in older adults current guidelines suggest, considering treatment on an individual basis according to symptoms and possible treatment benefit. 7 Hence this study is undertaken to know the burden and spectrum of thyroid dysfunction in elderly population.

Material \&methods: This study was conducted on 100 elderly patients in the department of medicine, $\mathrm{PMCH}, \mathrm{Patna}$ All patients of age more than 65 yearswith clinical suspicious of thyroid disorders were included in this study. All suspicious patients were examined clinically for detection of thyroid disorders.The laboratory evaluation of thyroid functions was done by estimation of serum T3, T4 and TSH levels by Chemiluminescence assay method. chi-square test was used for statistical data analysis.

\begin{tabular}{l|l|l}
\hline Submitted : 20 $^{\text {th }}$ September, 2019 & Revised : $17^{\text {th }}$ November, 2019
\end{tabular}

\section{RESULTS:}

In this study, 100 elderly patients who were suspected to be having thyroid disease as per inclusion \& exclusion criteria were evaluated in detail with clinical examination and laboratory investigations, including thyroid function tests and TPO antibodies.

1. 30 patients detected with abnormal thyroid function tests are as follows

Table 1: Spectrum of Thyroid Disorders in elderly

\begin{tabular}{|c|c|c|}
\hline Thyroid Disorders & No of cases & Percentage (\%) \\
\hline Normal & 70 & 70 \\
\hline Hypothyroidism & 13 & 13 \\
\hline Subclinical hypothyroidism & 10 & 10 \\
\hline Hyperthyroidism & 3 & 3 \\
\hline Subclinical hyperthyroidism & 4 & 4 \\
\hline
\end{tabular}

Overt clinical state was seen in more number of cases than Sub clinical state(13:10)in hypothyroidism whereas, subclinical state was more common in hyperthyroidism in the ratio of $3: 4$.

2.In the present study of 100 patients, 38 were males and 62 were females. We have found that prevalence of thyroid dysfunction was more among females (22\%) than in males (8\%) With a ratio of $11: 4$.This may be because of increased autoimmune diseases observed in females.

3.In the present study, prevalence of thyroid disorders in male and female are as follows

4.As the age advances, the incidence of thyroid disorder also increases. when it was observed statistically between the groups, it was found significant p value- 0.001 .

Table 2: Sex distribution of thyroid dysfunction in elderly-

\begin{tabular}{|c|c|c|c|}
\hline & Males & Females & Total \\
\hline Hypothyroidism & 6 & 17 & 23 \\
\hline Clinical & $3(7.8 \%)$ & $13(16 \%)$ & \\
\hline Subclinical & $3(7.8 \%)$ & $7(11.6 \%)$ & \\
\hline Hyperthyroidism & 2 & 5 & 7 \\
\hline Clinical & $1(2.6 \%)$ & $2(3.3 \%)$ & \\
\hline
\end{tabular}

Accepted : 28 $^{\text {th }}$ December, 2019 Publication : $15^{\text {th }}$ February, 2020 


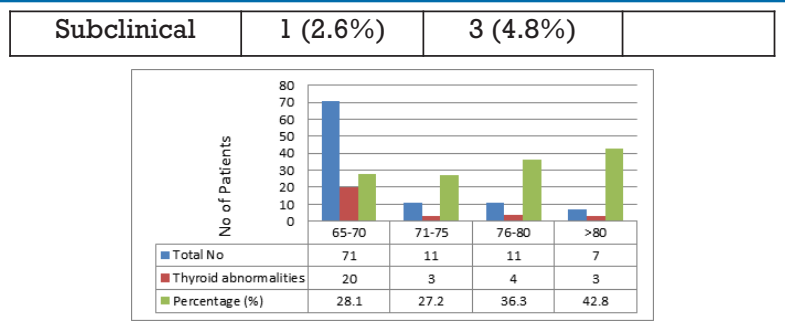

5.When the symptoms were analysed on the basis of clinical state, they are as follows -

Table 3: Symptoms of Hypothyroidism:

\begin{tabular}{|c|c|c|}
\hline & $\begin{array}{c}\text { Clinical(In\% } \\
(\mathrm{n}=13)\end{array}$ & $\begin{array}{c}\text { Subclinical (In \%) } \\
(\mathrm{n}=10)\end{array}$ \\
\hline Easy fatiguability & $13(100 \%)$ & $10(100 \%)$ \\
\hline $\begin{array}{c}\text { Generalised } \\
\text { weakness }\end{array}$ & $13(100 \%)$ & $10(100 \%)$ \\
\hline $\begin{array}{c}\text { Lethargy/disinter } \\
\text { est in } \\
\text { dailyActivities }\end{array}$ & $8(61.5 \%)$ & $4(40 \%)$ \\
\hline Anorexia & $7(53.8 \%)$ & $3(30 \%)$ \\
\hline $\begin{array}{c}\text { Swelling of } \\
\text { limbs/face }\end{array}$ & $9(69.2 \%)$ & $4(40 \%)$ \\
\hline Weight gain & $8(61.5 \%)$ & $3(30 \%)$ \\
\hline Constipation & $5(38.4 \%)$ & $1(10 \%)$ \\
\hline
\end{tabular}

Table 4: Signs of hypothyroidism:

\begin{tabular}{|c|c|c|}
\hline & $\begin{array}{c}\text { Clinical (in } \\
\%)(n=13)\end{array}$ & $\begin{array}{c}\text { Subclinical (in } \\
\%)(n=10)\end{array}$ \\
\hline Sluggish ankle jerk & $8(61.5 \%)$ & $2(15.3 \%)$ \\
\hline Dry /coarse skin & $7(53.8 \%)$ & $2(15.3 \%)$ \\
\hline Hoarseness & $7(53.8 \%)$ & $1(7 \%)$ \\
\hline Goitre & $3(23.0 \%)$ & - \\
\hline $\begin{array}{c}\text { Bradycardia (50 } \\
-60 / m i n)\end{array}$ & $4(30.7 \%)$ & - \\
\hline
\end{tabular}

Table 5: Symptoms of Hyperthyroidism:

\begin{tabular}{|c|c|c|}
\hline & $\begin{array}{c}\text { Clinical (in \%) } \\
(\mathrm{n}=3)\end{array}$ & $\begin{array}{c}\text { Subclinical (in \%) } \\
(\mathrm{n}=4)\end{array}$ \\
\hline $\begin{array}{c}\text { Heat intolerane, } \\
\text { sweating, } \\
\text { palpitations }\end{array}$ & $3(100 \%)$ & - \\
\hline Weight loss & $23100 \%)$ & - \\
\hline $\begin{array}{c}\text { Increased } \\
\text { appetite }\end{array}$ & $3(100 \%)$ & $2(50 \%)$ \\
\hline Diarrhoea & - & - \\
\hline
\end{tabular}

Table 6: Signs of Hyperthyroidism:

\begin{tabular}{|c|c|c|}
\hline & Clinical (\%)(n=3) & Subclinical (\%) (n=4) \\
\hline Tremors & $3(100 \%)$ & $1(25 \%)$ \\
\hline Goitre & $1(33.3 \%)$ & - \\
\hline $\begin{array}{c}\text { Tachycardia } \\
(110-120 / \mathrm{min})\end{array}$ & $3(100 \%)$ & - \\
\hline
\end{tabular}

No of patients with hyperthyroidism were less (7), out of which 3 had frank features of hyperthyroidism and 4 had subclinical hyperthyroidism, of which one case had feature of hyperthyroidism.

THYROID FUNCTION TESTS: The mean TSH values were higher \& T3 \&T4 values were lower in patients with overt hypothyroidism. Subclinical hypothyroidism cases had high TSH values but T3, T4 values were with in normal range. Patients with overt hyperthyroidism had low TSH values, with increased T3, T4 levels, whereas subclinical hyperthyroid |www.worldwidejournals.com| patients demonstrated a normal T3, T4 values with reduced TSH levels.

Table 7: Table showing the Mean and SD for normal subjects and for different thyroid disorders:

\begin{tabular}{|c|c|c|c|c|c|}
\hline & $\begin{array}{c}\text { TFT } \\
\text { in } \\
\text { Normal } \\
\text { cases } \\
(\mathrm{n}=70)\end{array}$ & $\begin{array}{c}\text { Hypothyro } \\
\text { idism } \\
(\mathrm{n}=13)\end{array}$ & $\begin{array}{c}\text { Subclinical } \\
\text { Hypothyroi } \\
\text { dism } \\
(\mathrm{n}=10)\end{array}$ & $\begin{array}{c}\text { Hyperthy } \\
\text { roidism } \\
(\mathrm{n}=3)\end{array}$ & $\begin{array}{c}\text { Subclinical } \\
\text { Hyperthyroi } \\
\text { dism }(\mathrm{n}=4)\end{array}$ \\
\hline TSH & $\begin{array}{c}2.71 \pm 1 . \\
66\end{array}$ & $\begin{array}{c}60.10 \pm \\
28.72\end{array}$ & $\begin{array}{c}13.67 \pm \\
3.30\end{array}$ & 0.01 & $0.27 \pm 0.19$ \\
\hline T3 & $\begin{array}{c}1.20 \pm 0 . \\
52\end{array}$ & $0.74 \pm$ & $1.20 \pm 0.38$ & $5.76 \pm$ & $1.91 \pm 1.01$ \\
& 0.56 & & 1.44 & \\
\hline T4 & $6.92 \pm 1$. & $2.84 \pm$ & $5.72 \pm 2.84$ & $24.72 \pm$ & $8.88 \pm 2.13$ \\
& 70 & 2.48 & & 3.94 & \\
\hline
\end{tabular}

TPO antibodies were estimated in all cases with altered thyroid functions. TPO was positive in 18 cases $(68 \%)$ of these cases. All patients with hypothyroidism had positive TPO antibodies, probably indicating auto immune cause for this disorder.

\section{LIPID ABNORIMALITIES AND THYROIDDYSFUNCTION}

Thyroid function abnormalities were seen in only $30 \%$ patients, but lipid abnormalities were seen in $36 \%$ patients. This could be because of other cause of dyslipidemia seen in these elderly patients like DM, obesity. Not all patients with hypothyroidism had dyslipidemia. It was observed only in $36 \%$ patients with abnormal thyroid functions. Hyperthyroidism had a lesser incidence (6\%) of lipid alterations

Figure 2: Thyroid state and lipid abnormalities:

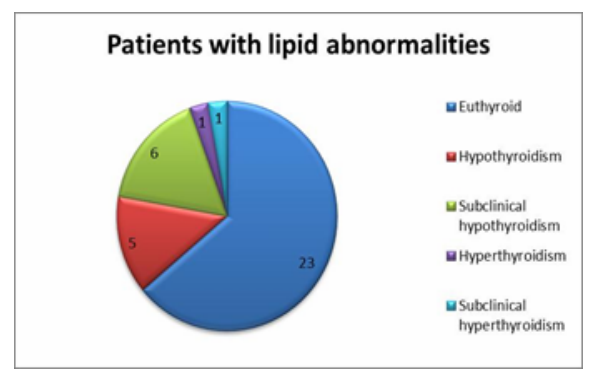

The thyroid hormone is known to play a role in regulating the synthesis, metabolism, and the mobilization of lipids. So patients with thyroid dysfunction have higher values of TGs, Total holesterol and LDL which was found to be statistically significant. ( $p$ value $<0.05$ ).

In hypothyroidism, the depletion of the thyroid hormones leads to a reduced number of LDL receptors in the liver, thereby decreasing the biliary excretion of cholesterol, thus resulting in elevated serum LDL and VLDL levels. It also decreases the lipoprotein lipase activity and causes hypertriglyceridaemia.

Table 8: Comparison of lipids in different thyroid abnormalities:

Mean and SD for various biochemical values of lipids in patients with dysfunction

\begin{tabular}{|c|c|c|c|c|}
\hline $\begin{array}{c}\text { Param } \\
\text { eter }\end{array}$ & $\begin{array}{c}\text { Hypothyroidi } \\
\mathrm{sm}\end{array}$ & $\begin{array}{c}\text { Subclinical } \\
\text { Hypothyroidis } \\
\mathrm{m}\end{array}$ & $\begin{array}{c}\text { Hyperthyro } \\
\text { idism }\end{array}$ & $\begin{array}{c}\text { Subclinical } \\
\text { Hyperthyroi } \\
\text { dism }\end{array}$ \\
\hline TG & $\begin{array}{c}221.27 \pm 72.9 \\
4\end{array}$ & $206.66 \pm 69.16$ & $\begin{array}{c}169.5 \pm 43.1 \\
3\end{array}$ & $175 \pm 85.77$ \\
\hline T.Chol & $\begin{array}{c}203.54 \pm 50.5 \\
1\end{array}$ & $216.22 \pm 67.14$ & $\begin{array}{c}189.5 \pm 20.5 \\
0\end{array}$ & $\begin{array}{c}140.66 \pm 34.4 \\
8\end{array}$ \\
\hline HDL & $44.09 \pm 12.91$ & $44.33 \pm 10.30$ & $42.5 \pm 2.12$ & $39 \pm 12.52$ \\
\hline
\end{tabular}




\begin{tabular}{|c|c|c|c|c|}
\hline LDL & $120.0 \pm 48.57$ & $129.33 \pm 57.20$ & $119.0 \pm 18.3$ & $103.33 \pm 26.5$ \\
8 & 7
\end{tabular}

Patients with overt hypothyroidism have increased levels of TGs as compared to other lipids. We noted that patients with subclinical hypothyroidism have increased levels of total cholesterol and LDL levels as compared to overt hypothyroidism, but it was not found to be statistically significant.

It may be explained by the presence of other comorbid conditions and confounding factors like overweight, DM that were present in subclinical hypothyroid patients. Hyperthyroidism was not associated with gross lipid alterations. HDL levels were normal in all groups.ECG changes were seen in 10 patients. The heart rate in subjects with bradycardia was between $50-60 / \mathrm{min}$, and in subjects with tachycardia was between 110-120/min. Cardiovascular involvement in these cases is in the form of variability of $\mathrm{HR}$ depending on the thyroid state. Long standing hypothyroid state can lead to IHD as in one of our case. VPC may not be related to thyroid disorder. One patient with overt hypothyroidism demonstrated a mild pericardial effusion.

USG and FNAC were done in 4 patients having thyroid swelling. Among patients having goitre, 3 of them had hypothyroidism and one had hyperthyroidism. Hashimoto's thyroiditis was seen in one subject.

Discussion: The present study is compared with other studies from India \& abroad, it shows some variation in the pattern of the disease. It may be because of variation in sample size or ethnic variation.

Table 9. Comparative studies prevalence of Thyroid disorders in elderly and sex wise distribution

\begin{tabular}{|c|c|c|c|}
\hline & $\begin{array}{c}\text { Cappola, A. } \\
\text { R. et al. }\end{array}$ & $\begin{array}{c}\text { Marwaha, R. } \\
\text { K. et al. }\end{array}$ & $\begin{array}{c}\text { Present } \\
\text { study }\end{array}$ \\
\hline $\begin{array}{c}\text { Total thyroid } \\
\text { abnormality \% }\end{array}$ & 18.33 & 28.8 & 30 \\
\hline Male \% & 4.43 & 11.2 & 8 \\
\hline Female \% & 13.9 & 17.6 & 22 \\
\hline
\end{tabular}

We have found that $30 \%$ patients have thyroid disorders. We have noted that as the age advances the incidence of thyroid dysfunction increases ( $p$ value significant).

Thyroid abnormalities seen in different studies were variable. Western studies show a lower incidence compared to Indian series. It may be due to selection bias as present study has selected strongly suspicious cases for the study. Another factor is the numbers of cases studied by the other authors are more. Hence the incidence may be less in other series than the present series.

We noted a higher prevalence of thyroid dysfunction in females which is comparable to other studies, because of autoimmune nature of the disease. This could be attributed to the late presentation of the rural population who had lack of knowledge about their symptoms. May be due to genetic factors also.

\section{CONCLUSION:}

Aim of this study was to know the various clinical aspect of presentation of thyroid dysfunction in the elderly population that differ from typical presentation. Hypothyroidism was more common than hyperthyroidism. Incidence of thyroid dysfunction increases with increased age.

\section{REFERENCES:}

1. Rebecca Abraham,V.SrinivasMurugan,P.Pukazhvanthen, S.K.Sen. Thyroid disorder in women of Puducherry. Indian Journal of Clinical Biochemistry2009;24(1):52-59.

2. Sawin CT, Castelli WP, Hershman JM, McNamara P, Bacharach P. The aging thyroid.Thyroid deficiency in the Framingham Study:Arch Intern Med 1985;145:1386-1388.
3. Shakib U Rehman, Dennis.W.Cope, Anna D Senseney, Walter brezezinski. Thyroid disorders in elderly:Southern medical journal2005;98(5):543-549.

4. Papaleontiou\&Haymart: Approach to and Treatment of Thyroid Disorders in the Elderly: Med Clin N Am 96 (2012) 297-310.

5. Bahn RS, Burch HB, Cooper DS, et al. Hyperthyroidism and other causes of thyrotoxicosis: management guidelines of the American Thyroid Association and American Association of Clinical Endocrinologists. EndoPract 2011;17(3):456-52

6. Bemben DA, Winn P, Hamm RM, Morgan L, Davis A, Barton E. Thyroid disease in the elderly. Part 1. Prevalence of undiagnosedhypothyroidism. J Fam Pract $1994 ; 38: 577-82$ 